\title{
Biochemical profile of Mangalarga Marchador mares during the last third of pregnancy, foaling and lactation
}

\author{
Micheline Ozana da Silva ${ }^{1^{*}}$ José Dantas Ribeiro Filho ${ }^{1}$ (D) Waleska de Melo Ferreira Dantas ${ }^{1}$ \\ Bruna Maria Ribeiro ${ }^{1}$ (D) Pedro Ancelmo Nunes Ermita ${ }^{2}$ (D) Lorena Chaves Monteiro ${ }^{1}$ (iD \\ Caio Monteiro Costa ${ }^{1}$ (D) Glaucia Matos Marques da Silva ${ }^{1}$ (D) Samuel Rodrigues Alves ${ }^{1}$ (D) \\ Marcel Ferreira Bastos Avanza ${ }^{1}$ (D) Paulo Vinicius de Morais Santos ${ }^{1}$ iD \\ Hélio Cordeiro Manso Filho $^{3}$ id
}

1Departamento de Veterinária, Universidade Federal de Viçosa (UFV), 36570-900, Viçosa, MG, Brasil. E-mail: michelineozana@gmail.com. ${ }^{*}$ Corresponding author.

${ }^{2}$ Instituto de Estudos do Trópico Úmido (IETU), Universidade Federal do Sul e Sudeste do Pará (Unifesspa), Xinguara, PA, Brasil. ${ }^{3}$ Departamento de Zootecnia, Universidade Federal Rural de Pernambuco (UFRPE), Recife, PE, Brasil.

ABSTRACT: Adaptive changes in metabolism may occur under specific physiological conditions, being necessary the knowledge of the biochemical constituents that can undergo variations during the sixty days before foaling, until the first sixty days of lactation. The present study aimed to identify and evaluate the biochemical profile of Mangalarga Marchador mares during the last third of pregnancy, foaling and lactation. For this, 48 mares were used, which formed a maintenance group $(M G)$, composed of non-pregnant mares and an experimental group, called the transition group (TG), formed by pregnant mares. Blood samples were collected at the following times: MG was evaluated in a single time (beginning of all collections); TG was evaluated in seven times [T-60, T-30, T-15 (days before foaling), T0 (first six hours after foaling), T15, T30, T60 (days after foaling)]. All animals were submitted to biochemical analysis, in which the concentrations of total calcium, chloride, phosphorus, magnesium, sodium, potassium, uric acid, creatinine, and urea were measured. The two groups differed significantly $(P<0.05)$ in calcium, magnesium, sodium, potassium, creatinine, uric acid and urea concentration. Variation between times was also observed for these compounds. However, chloride and phosphorus did not differ between MG and TG. It was concluded that the last third of pregnancy, foaling and lactation exerts major influence on the biochemical constituents of blood through adjustments to maintain homeostasis in mares. Key words: delivery, equine, metabolic parameters, peripartum.

Perfil bioquímico de éguas da raça Mangalarga Marchador durante o terço final da gestação, parto e lactação

\begin{abstract}
RESUMO: Mudanças adaptativas no metabolismo podem ocorrer em condições fisiológicas especificas, sendo necessário o conhecimento dos constituintes bioquímicos que possam sofrer variações durante os sessenta dias antes do parto, até os primeiros sessenta dias de lactação. O presente estudo teve como objetivo identificar e avaliar o perfil bioquímico de éguas Mangalarga Marchador no terço final da gestação, parto e lactação. Para isso, foram utilizadas 48 éguas, que formaram um grupo em manutenção (GM), composto por éguas não prenhes e um grupo experimental, chamado de grupo de transição $(G T)$, formado por éguas gestantes. As coletas de sangue foram realizadas nos seguintes tempos: GM foi avaliada em um único tempo (início de todas as coletas); GT foi avaliado em sete tempos [T-60, T-30, T-15 (dias antes do parto), T0 (primeiras seis horas após o parto), T15, T30, T60 (dias após o parto)]. Todos animais foram submetidos as análises bioquímicas, em que foram mensuradas as concentrações de cálcio total, sódio, potássio, cloreto, fósforo, magnésio, ácido úrico, creatinina e ureia. Os dois grupos diferiram significativamente $(P<0,05)$ nas concentrações de cálcio total, magnésio, sódio, potássio, creatinina, ácido úrico e ureia. Variações entre tempos também foram observadas nesses componentes. Entretanto, cloreto e fósforo não diferiram entre GM e GT. Conclui-se que o terço final da gestação, parto e lactação exerce forte influência sobre os constituintes bioquímicos do sangue por meio de ajustes para manter a homeostase nas éguas.
\end{abstract}

Palavras-chave: equinos, parâmetros metabólicos, parto, periparto.

\section{INTRODUCTION}

Pregnancy is a dynamic physiological condition that alters metabolism of all maternal nutrients (BAZZANO et al., 2014). Transition period is the interval between parturition and early lactation (MANSO FILHO et al., 2008). As the fetus develops, biochemical parameters change to mark different gestational phases (NASEEMA et al., 2017). Ideal conditions are essential to ensure intrauterine 
development and the fetus survival. In mares, there is a reduction in food intake at the end of pregnancy, due to fetal size compressing the abdominal internal space. This phase occurs to higher fetal metabolic demand. Post foaling energetic demands continue with milk production to meet foal nutritional needs, while mares also require energy to recover in the postpartum period (HURA et al., 2017).

In this period, alters mare's biochemical profile (FAZIO et al., 2016), with adjustments occurring during gestation and lactation, even as homeostatic mechanisms ensure that individual components remain constant (HARVEY et al., 2005). In the last trimester, there is an increase in the nutritional demand of pregnant mare, which can lead to a greater susceptibility to disease development (BAZZANO et al., 2014), due to mineral imbalances such as hypocalcemia (FILIPOVIC et al., 2010) and metabolic syndromes (JOHNSON et al., 2009).

Serum parameters differ across reproductive stages, with some of these changes potentially resulting in pathological conditions. For instance, potassium and creatinine concentrations are lower during lactation than during pregnancy (HARVEY et al., 2005). Several studies have described the major biochemical characteristics of transition period mares across different breeds (MARIELLA et al., 2014; VINCZE et al., 2015; HURA et al., 2017). To understand how different physiological conditions in the last third of pregnancy, foaling and lactation affect mares, the aim of the research was to evaluate the biochemical profile of Mangalarga Marchador mares during the last third of pregnancy, foaling and lactation.

\section{MATERIALS AND METHODS}

Forty-eight Mangalarga Marchador mares were divided into a maintenance group (MG) consisting of non-pregnant and non-lactating mares $(n=22)$ at baseline, and a transition group (TG) $(n=26)$ composed of mares pregnant at the end of the third (sixty days before foaling). Mares were healthy, 5-15 year-olds, selected from a herd of 180 animals in Brazil. Transition group mares were selected, so that their probable foaling dates were concentrated within the 30th day period of the highest foaling frequency.

Mares were kept in pasture (approximately $300 \mathrm{~m}^{2}$ ) with ad libitum access to Tifton (Cynodon spp.) grass, water, and commercial mineralized salt (Coequi Plus, Tortuga). Animals were kept in maternity paddocks from two weeks before until two weeks postpartum, without change in diet. Post-partum mares were then transferred to a Tifton pasture containing only other females under the same conditions.

Blood samples were always harvested between 8:00am and 11:00am. Samples from MG mares were collected in a single time (in the beginning of all blood collections), while TG mares were evaluated at seven different times: T-60, T-30, T-15 (days before foaling), T0 (6 hours after foaling), T15, T30, T60 (days after foaling).

Blood was collected from the mares without prior fasting. After antisepsis, blood was drawn from the jugular vein using disposable needles and vials to vacuum siliconized without anticoagulant, $10 \mathrm{ml}$ (Labor Import, Osasco, SP, Brazil). These vials were kept at approximately $27{ }^{\circ} \mathrm{C}$ until clot retraction, and then centrifuged for $5 \mathrm{~min}$ at $1500 \times g$ (Centrifuge Excelsa 2206, Fanem, Guarulhos, SP, Brazil). The resultant supernatant was aliquoted into microtubes and immediately frozen at $-20{ }^{\circ} \mathrm{C}$. With the exception of sodium and potassium quantification (through flame photometry), all analyses were performed in a Humastar 300 automatic device (Human, In Vitro Diagnóstica Ltda, Itabira, MG).

The colorimetric method was used to measure total calcium (O-cresolphthalein-complex CFC), magnesium (Xilidila Blue), chloride (mercury trocyanate), and phosphorus (ammonium molybdate). Sodium, potassium (Chama, Model B462, MicroNal), urea (GLDH method), creatinine (colorimetric kinetic method) and uric acid (UOD-PAP enzymatic colorimetric method) analysis were also examined.

For data analysis, the Statistical Analysis System was used. Data were evaluated by the Kolmogorov-Smirnov and Bartlett tests to verify the normality of errors and homogeneity of variances, respectively. The data of pregnant mares were analyzed in linear mixed models with repeated measures in time using PROC MIXED (SAS, 2002), with autoregressive covariance structure and animal as a random effect (LITTELL et al., 2006), according to the mathematical model:

$$
Y_{i j k}=\mu+\beta_{i}+Y_{j}+e_{i j k}
$$

Where, $Y_{i j k}=$ response; $\mu$ = constant; $\beta_{i}=$ fixed effect (time); $Y_{j}=$ random effect (animal); $e_{i j k}=$ error. The least square means were compared by Tukey-Kramer test. Additionally, the mean of times was compared to maintenance group by Dunnett's test. Significant level adopted was $\alpha=0.05$.

\section{RESULTS}

During the experiment, the minimum and maximum average temperatures were $17.4^{\circ} \mathrm{C}$ and 28.6 
${ }^{\circ} \mathrm{C}$, respectively, while average relative humidity was $49 \%$. Mares remained healthy throughout pregnancy, deliveries were eutocic, occurring at night without human assistance. The mares of this study showed no agalactia in the physical examination performed by a veterinarian. All foals were breastfed in the first hours after foaling. Total calcium concentration was lowest in $\mathrm{MG}$ mares $(2.79 \pm 0.53)$, differing from that in the TG mares at T60 $(\mathrm{P}<0.05)$. In TG mares, calcium concentration was significantly $(\mathrm{P}<0.05)$ higher at $\mathrm{T} 60(3.15 \pm 0.31)$ than at $\mathrm{T} 15(2.73 \pm 0.36)$.

Chloride levels did not differ significantly between the mare groups $(\mathrm{P}>0.05)$. However, TG mares had higher $(\mathrm{P}<0.05)$ mean chloride concentration at $\mathrm{T}-15(101.85 \pm 7.55)$ than at $\mathrm{T} 0$ $(90.65 \pm 28.85)$. Magnesium concentration was higher $(\mathrm{P}<0.05)$ in $\mathrm{MG}(1.96 \pm 0.64)$ than in $\mathrm{TG}$ mares at $\mathrm{T}-15(1.45 \pm 0.32), \mathrm{T} 0(1.30 \pm 0.37), \mathrm{T} 15$ $(1.26 \pm 0.54)$, and $\mathrm{T} 30(1.34 \pm 0.50)$. These temporal differences within TG mares were significant $(\mathrm{P}<0.05)$. Phosphorus values was similar across the two groups $(\mathrm{P}>0.05)$, but differed temporally within TG mares; specifically, T-30 concentrations were distinct $(\mathrm{P}<0.05)$ from those at $\mathrm{T}-60, \mathrm{~T}-15, \mathrm{~T} 0, \mathrm{~T} 15$, and T60 (Table 1).

Sodium concentration in $\mathrm{MG}$ mares $(154.60 \pm 10.87)$ differed significantly $(\mathrm{P}<0.05)$ from concentrations in TG mares at T0 $(170.07 \pm 10.38)$ and T60 (131.68 \pm 19.60$)$. Temporal difference among TG mares was significant $(\mathrm{P}<0.05)$. Except at T15 and T60, both groups exhibited sodium levels above the reference range for horses.

Potassium differed $(\mathrm{P}<0.05)$ between the two groups at three times (T-15, T0, and T60). Within TG mares, was observed a significant difference in potassium levels over time $(\mathrm{P}<0.05)$. Mares at $\mathrm{T} 60$ possessed less potassium than at other time points. Mares at T15 also differed in potassium levels from mares at $\mathrm{T}-15$ and $\mathrm{T} 0$. Overall, mean potassium values progressively decreased in lactating mares.

Uric acid concentration differed $(\mathrm{P}<0.05)$ between MG $(\mathrm{P}<0.05)$ and TG mares at T-30. Among TG mares, mean uric acid levels were higher at T-30 $(1.00 \pm 0.15)$ than at $\mathrm{T} 30(0.65 \pm 0.09 ; \mathrm{P}<0.05)$. Creatinine concentration was also significantly higher $(\mathrm{P}<0.05)$ in $\mathrm{MG}$ than in TG mares at three times ( $\mathrm{T}$ 30, T-15, and T0). Temporal differences within TG mares were significant $(\mathrm{P}<0.05)$. Mean creatinine levels increased during gestation and parturition, but then decreased during lactation (Table 1).

At T-60 and T-30, urea concentration was higher $(\mathrm{P}<0.05)$ in $\mathrm{MG}$ mares than in $\mathrm{TG}$ mares. However, the observed concentration was well within the standard for this breed. It was observed a clear difference in urea over time among TG mares (Table 1).

\section{DISCUSSION}

The research demonstrated that most blood biomarkers changed significantly during the

Table 1 - Mean values and standard deviations of the concentrations of macro-minerals: total calcium $(\mathrm{Ca}, \mathrm{mmol} / \mathrm{L})$, chloride $(\mathrm{Cl}$, $\mathrm{mmol} / \mathrm{L})$, magnesium $(\mathrm{Mg}, \mathrm{mmol} / \mathrm{L})$, phosphorus $(\mathrm{P}, \mathrm{mmol} / \mathrm{L})$, sodium $(\mathrm{Na}, \mathrm{mmol} / \mathrm{L})$ and potassium $(\mathrm{K}, \mathrm{mmol} / \mathrm{L})$; and nitrogen compounds: uric acid $(\mathrm{UA}, \mathrm{mg} / \mathrm{dL})$, creatinine $(\mathrm{Cr}, \mathrm{mg} / \mathrm{dL})$ and urea $(\mathrm{U}, \mathrm{mmol} / \mathrm{L})$ in mares of transition group $(\mathrm{TG})$ and mares of maintenance group (MG).

\begin{tabular}{|c|c|c|c|c|c|c|c|c|}
\hline \multirow{3}{*}{$\begin{array}{l}\text { Blood } \\
\text { Parameters }\end{array}$} & \multicolumn{7}{|c|}{ 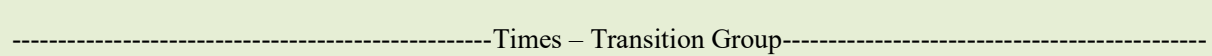 } & \multirow{2}{*}{$\begin{array}{c}\text { Maintenance } \\
\text { group }\end{array}$} \\
\hline & \multicolumn{3}{|c|}{------------------Pregnancy-------------------- } & \multicolumn{2}{|c|}{-----------Delivery----------- } & \multicolumn{2}{|c|}{ 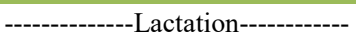 } & \\
\hline & $\mathrm{T}-60$ & $\mathrm{~T}-30$ & $\mathrm{~T}-15$ & T0 & $\mathrm{T} 15$ & $\mathrm{~T} 30$ & T60 & MG \\
\hline $\mathrm{Ca}$ & $3.0 \pm 0.6^{\mathrm{ab}}$ & $3.0 \pm 0.4^{\mathrm{ab}}$ & $3.0 \pm 0.1^{\mathrm{ab}}$ & $3.0 \pm 0.3^{\mathrm{ab}}$ & $2.7 \pm 0.3^{\mathrm{b}}$ & $2.9 \pm 0.3^{\mathrm{ab}}$ & $3.1 \pm 0.3^{\mathrm{a}^{*}}$ & $2.7 \pm 0.5$ \\
\hline $\mathrm{Cl}$ & $98.6 \pm 2.6^{\mathrm{ab}}$ & $98.9 \pm 3.0^{\mathrm{ab}}$ & $101.8 \pm 7.5^{\mathrm{a}}$ & $90.6 \pm 28.8^{b}$ & $97.2 \pm 3.6^{\mathrm{ab}}$ & $99.0 \pm 3.4^{\mathrm{ab}}$ & $98.6 \pm 3.4^{\mathrm{ab}}$ & $95.1 \pm 3.3$ \\
\hline $\mathrm{Mg}$ & $1.6 \pm 0.2^{\mathrm{bc}}$ & $2.0 \pm 0.8^{\mathrm{a}}$ & $1.4 \pm 0.3^{\text {bcd* }}$ & $1.3 \pm 0.3^{\text {cd }^{*}}$ & $1.2 \pm 0.5^{\mathrm{d}^{*}}$ & $1.3 \pm 0.5^{\text {bcd* }}$ & $1.7 \pm 0.4^{\mathrm{ab}}$ & $1.9 \pm 0.6$ \\
\hline $\mathrm{P}$ & $1.4 \pm 0.2^{\mathrm{a}}$ & $1.0 \pm 0.1^{\mathrm{b}}$ & $1.4 \pm 0.3^{\mathrm{a}}$ & $1.3 \pm 0.3^{\mathrm{a}}$ & $1.2 \pm 0.1^{\mathrm{a}}$ & $1.2 \pm 0.2^{\mathrm{ab}}$ & $1.4 \pm 0.3^{\mathrm{a}}$ & $1.2 \pm 0.3$ \\
\hline $\mathrm{Na}$ & $164.9 \pm 9.3^{\mathrm{ab}}$ & $157.5 \pm 16.7^{\mathrm{abc}}$ & $160.8 \pm 6.9^{\mathrm{ab}}$ & $170.0 \pm 10.3^{\mathrm{a}^{*}}$ & $147.9 \pm 16.5^{\mathrm{c}}$ & $153.8 \pm 19.1^{\mathrm{bc}}$ & $131.6 \pm 19.6^{\mathrm{d}^{*}}$ & $154.6 \pm 10.8$ \\
\hline $\mathrm{K}$ & $5.5 \pm 0.5^{\mathrm{ab}}$ & $5.4 \pm 0.9^{\mathrm{ab}}$ & $6.1 \pm 0.8^{\mathrm{a}^{*}}$ & $6.0 \pm 0.4^{\mathrm{a}^{*}}$ & $4.9 \pm 1.4^{b}$ & $4.8 \pm 0.7^{\mathrm{bc}}$ & $4.1 \pm 0.5^{\mathrm{c}^{*}}$ & $5.0 \pm 0.6$ \\
\hline UA & $0.8 \pm 0.1^{\mathrm{abc}}$ & $1.0 \pm 0.1^{\mathrm{a}^{*}}$ & $0.8 \pm 0.0^{\mathrm{ab}}$ & $0.9 \pm 0.2^{\mathrm{a}}$ & $0.7 \pm 0.1^{\mathrm{bc}}$ & $0.6 \pm 0.0^{c}$ & $0.8 \pm 0.1^{\mathrm{abc}}$ & $0.7 \pm 0.1$ \\
\hline $\mathrm{Cr}$ & $1.2 \pm 0.2^{b}$ & $1.4 \pm 0.2^{\mathrm{a}^{*}}$ & $1.4 \pm 0.2^{\mathrm{a}^{*}}$ & $1.4 \pm 0.2^{\mathrm{a}^{*}}$ & $1.1 \pm 0.1^{\mathrm{bc}}$ & $1.0 \pm 0.1^{\mathrm{c}}$ & $0.9 \pm 0.1^{\mathrm{c}}$ & $1.1 \pm 0.1$ \\
\hline $\mathrm{U}$ & $4.9 \pm 0.9^{c^{*}}$ & $5.2 \pm 1.1^{\mathrm{bc} *}$ & $5.9 \pm 1.1^{\mathrm{ab}}$ & $5.9 \pm 1.3^{\mathrm{ab}}$ & $5.9 \pm 1.2^{\mathrm{abc}}$ & $6.3 \pm 1.2^{\mathrm{a}}$ & $6.4 \pm 1.1^{\mathrm{a}}$ & $6.5 \pm 1.4$ \\
\hline
\end{tabular}

Means followed by lower case letters on the same line differ $(\mathrm{P}<0.05)$ by the Tukey test. Means followed by an asterisk $\left({ }^{*}\right)$ on the same row differ $(\mathrm{P}<0.05)$ in the group maintenance by Dunnet's test. 
last third of pregnancy, foaling and lactation, including macrominerals (calcium, chloride, magnesium, sodium, phosphorus and potassium), urea, creatinine, and uric acid (Table 1). Female reproductive stage influences mineral concentration, affecting both fertility and gestation success (ALI et al., 2013). Therefore, it is required a better understanding of female biochemical profiles across different physiological states and species (BERLIN \& AROCH, 2009).

The observed variation in macrominerals corroborated the results from other studies (BAZZANO et al., 2016; HURA et al., 2017). Indeed, calcium, chloride, phosphorus, magnesium, sodium, and potassium are all components of important regulatory molecules (HURA et al., 2017). Mineral deposition in the fetus occurs during the last two months of pregnancy, suggesting increasing intensity in fetal development (KAVAZIS et al., 2002). Additionally, major changes in serum electrolyte concentration occur during the two weeks prior to foaling and the first two weeks of lactation (Table 1) (BAZZANO et al., 2016).

Calcium is a necessary nutrient for fetal skeleton development. Its homeostasis in pregnant mares is regulated through transport from mare to fetus via the placenta, possibly under the control of an intrinsic fetal mechanism (CARE, 1997). In the last gestational trimester, fetus size increases along with anabolic activity (VINCZE et al., 2015). In this study, mean values of total calcium values remained within the reference range proposed for the species. It was observed the highest calcium concentrations in TG mares during pregnancy, foaling, and 60 days postpartum. The calcium is necessary for bone mineralization and maintaining normal physiological processes. Newborn foals require a higher amount of calcium and they can obtain it through breast milk in the first 6 months. A previous study on Mangalarga Marchador mares demonstrated that milk production increases until the second month of lactation before decreasing (SANTOS et al., 2005). This pattern suggested that nutritional demand is higher in the first 30 days of lactation. Likewise, it was observed the lowest calcium values at T15 and T30 (Table 1).

During the third final phase of pregnancy, mean calcium levels decrease compared to levels in non-pregnant and lactating mares (7 days postpartum) (BERLIN \& AROCH, 2009). Another study also described that calcium concentration is lower on the day of foaling than during non-pregnancy (MARIELLA et al., 2014). However, comparisons between studies are difficult, given the variations in laboratory methods, environment, nutrition and management.
Chloride concentration remained within the reference range for horses (KANEKO et al., 2008), despite a temporal difference between $\mathrm{T}-15$ and $\mathrm{T} 0$ in TG mares (Table 1). It was observed an increase in chloride at the end of gestation, corroborating the findings of previous research (NAGEL et al., 2016; NASEEMA et al., 2017). Chloride functions to regulate osmotic pressure, hydroelectrolyte balance, and acid-base homeostasis (GONZÁLES \& SILVA, 2006). Pre-delivery dehydration at around 20 days appears to elevate chloride concentration (NASEEMA et al., 2017). In the present study, chloride did not differ between groups, but its levels were the lowest at calving and early lactation (Table 1). These findings may be related to chloride excretion when lactating.

While all magnesium levels were higher than the reference value for horses (0.9-1.15 $\mathrm{mmol} / \mathrm{L}$ ) (KANEKO et al., 2008), it was observed low concentrations around foaling (T15 and T30). These patterns are in contrast to previous studies showing either unchanged magnesium levels (HURA et al., 2017), or a foaling and postpartum increase (MARIELLA et al., 2014). Magnesium present in bones is involved in muscle contraction (MARIELLA et al., 2014) and neuromuscular activity (GONZÁLES \& SILVA, 2006). However, due to the extensive breeding system to which the animals were kept, it was not possible to measure the food intake of magnesium in this study. Thus, it was not possible to determine whether the magnesium concentrations observed were related to animal feed.

Phosphorus concentration did not differ significantly between groups, remaining within the recommended reference range (KANEKO et al., 2008). However, TG mares did experience some temporal variation in phosphorus, with lower concentrations at 30 days before foaling. Together with calcium, phosphorus comprises approximately $70 \%$ of body mineral content and $50 \%$ of milk mineral content (BAZZANO et al., 2016), also like calcium, phosphorus is important in energy metabolism and bone structure. Phosphorus concentration in mares appeared to decrease between foaling and the first 30 days of lactation; although, the change was not significant. This observation is likely related to deviations in typical milk-phosphorus levels during lactation, given that colostrum production requires large amounts of phosphorus (MENEZES \& RIBEIRO FILHO, 2011).

Serum sodium in MG and TG mares was above the equine reference value (KANEKO et al., 2008) at all times except T15 and T60. Previous research showed that sodium concentrations are 
typically the highest during the last third of pregnancy and foaling (HARVEY et al., 2005; MARIELLA et al., 2014; BAZZANO et al., 2016; NAGEL et al., 2016), while a separate study reported higher sodium concentration in mares before foaling, possibly due to dehydration (NASEEMA et al., 2017). During pregnancy, hormonal changes tend to trigger a drop in blood pressure; therefore, sodium and water retention occurs to maintain blood pressure at normal levels (CARLIN \& ALFIREVIC, 2008). The reninangiotensin-aldosterone system is responsible for this process, regulating sodium excretion and bloodpressure fluctuation across the placental barrier (BAZZANO et al., 2016). Nevertheless, because it was reported high sodium concentrations in both TG and MG mares, transition-related physiological changes are likely not the sole cause of change. High sodium levels may be an intrinsic characteristic of the subject animals.

Potassium and sodium patterns were similar, with the former being above equine reference values at all times points except T60 (Table 1). Reduced potassium during lactation may be due to elevated activity from the reninangiotensin-aldosterone system (NAGEL et al., 2016). Higher sodium and chloride retention during pregnancy could also influence potassium levels. Lower potassium during lactation is in line with previous research (HARVEY et al., 2005). Overall, the observed patterns suggested a migration of potassium from mare serum to milk.

Very few studies have examined blood uric acid levels in horses and other species during the transition period. Uric acid is an antioxidant that protects against lipid, protein, and carbohydrate peroxidation (KIRSCHVINK et al., 2008). Increased oxygen demand during pregnancy typically increases oxidative stress (GÓRECKA et al., 2002). In the present study, it was reported uric acid concentration showed between-group and time differences. Specifically, uric acid was higher around foaling and then progressively declined in the first 30 days of lactation (Table 1). Previous research reported that 6-month-old pregnant mares did not differ significantly from lactating mares, either 2 weeks before or 4 weeks after foaling (GÓRECKA et al., 2002). Uric acid concentration may increase around foaling as a mechanism of protection against gestation-related oxidative stress.

Produced from creatine phosphate, creatinine is involved in muscle metabolism and is eliminated from circulation through urine. High blood creatinine may indicate renal malfunction (HURA et al., 2017) or other pathologies, it happens because the substance is typically present at low concentrations owing to effective renal filtration. It was observed high creatinine levels during pregnancy and foaling, followed by a progressive reduction during lactation (Table 1). Creatinine comportment are in line with the patterns observed from comparisons of Lipzzan mare creatinine profiles during the final third phase of gestation and during lactation (HARVEY et al., 2005; HURA et al., 2017).

As the creatinine level decreases in the absence of a fetus (Table 1) (MARIELLA et al., 2014; HURA et al., 2017), observed creatinine elevation in TG at T-30, T-15, and T0 is probably produced by maternal-fetal metabolism. A reduction in creatinine and urea concentrations can occur when the increased catabolism during lactation causes decreased muscle mass (HARVEY et al., 2005). The results (Table 1) support this hypothesis. In general, urea and creatinine can drop by up to $40 \%$ during pregnancy (TALBOT \& MACLENNAN, 2016). Other studies similarly reported that MG mares had higher mean urea concentration than TG mares, but values remained within the reference for horses (BAZZANO et al., 2014; MARIELLA et al., 2014; VINCZE et al., 2015). The tendency to reduce urea concentrations throughout gestation likely happens because heightened fetal metabolism and protein consumption leads to elevated protein anabolism.

\section{CONCLUSION}

The last third of pregnancy, foaling and lactation exerts major influence on the biochemical constituents of blood through adjustments to maintain homeostasis. Notably, mares in this study express increases in sodium, potassium, and magnesium concentrations. This research suggested that health transition mares can be objectively analyzed through measuring and interpreting blood biomarkers.

\section{ACKNOWLEDGEMENTS}

The authors are grateful to the Coordenação de Aperfeiçoamento de Pessoal de Nível Superior (CAPES) for the financial support (process No. 88887.308644/2018-00 PNPD/ CAPES) and also for the Fundação de Amparo à Pesquisa do Estado de Minas Gerais (FAPEMIG).

\section{BIOETHICS AND BIOSSECURITY COMMITTEE APPROVAL}

The project was previously approved for the Ethical Committee in the Use of Animals of the Universidade Federal de Viçosa (ECUA/UFV) with the protocol number 95/2015. 


\section{DECLARATION OF CONFLICT OF INTERESTS}

The authors declare no conflict of interest. The founding sponsors had no role in the design of the study; in the collection, analyses, or interpretation of data; in the writing of the manuscript, and in the decision to publish the results.

\section{AUTHORS' CONTRIBUTIONS}

All authors contributed equally for the conception and writing of the manuscript. All authors critically revised the manuscript and approved of the final version.

\section{REFERENCES}

ALI, F. et al. Serum mineral profile in various reproductive phases of mares. Pakistan Veterinary Journal, v.33, p.296-299, 2013. Available from: <http://pvj.com.pk/pdf-files/33 3/296-299.pdf>. Accessed: Dec. 17, 2015.

BAZZANO, M. et al. Metabolic profile of broodmares during late pregnancy and early post-partum. Reproduction in Domestic Animals, v.49, p.947-953, 2014. Available from: <https:// onlinelibrary.wiley.com/doi/full/10.1111/rda.12411>. Accessed: Mar. 14, 2016. doi: 10.1111/rda.12411.

BAZZANO, M. et al. The peripartum period influenced the serum macromineral profile in mares. Archives Animal Breeding, v.59, p.65-70, 2016. Available from: <https://www.arch-anim-breed. net/59/65/2016/aab-59-65-2016.pdf >. Accessed: Feb. 9, 2016. doi: 10.5194/aab-59-65-2016.

BERLIN, D.; AROCH, I. Concentrations of ionized and total magnesium and calcium in healthy horses: Effects of age, pregnancy, lactation, $\mathrm{pH}$ and sample type. Veterinary Journal, v.181, p.305-311, 2009. Available from: <https://www.ncbi. nlm.nih.gov/pubmed/18467135>. Accessed: Feb. 2, 2016. doi: 10.1016/j.tvj1.2008.03.014.

CARE, A.D. Fetal calcium homeostasis. Equine Veterinary Journal, v.24, p.59-61, 1997.

CARLIN, A.; ALFIREVIC Z. Physiological changes of pregnancy and monitoring. Best Practice \& Research: Clinical Obstetrics \& Gynaecology, v.22, p.801-823, 2008. Available from: <https://www.ncbi.nlm.nih.gov/pubmed/18760680>. Accessed: Sep. 14, 2016. doi: 10.1016/j.bpobgyn.2008.06.005.

FAZIO, E. et al. Seasonal thyroid and lipid profiles in Thoroughbred pregnant and nonpregnant mares (Equus caballus). Theriogenology, v.85, p.1582-1589, 2016. Available from: $<$ https://www.ncbi.nlm.nih.gov/pubmed/26920797>. Accessed: Feb. 10, 2016. doi: 10.1016/j.theriogenology.2016.01.017.

FILIPOVIC, N.; SOTOJEVIC, Z.; PRVANOVIC, N.; TUCEK $Z$. The influence of late pregnancy and lactation on bone metabolism in mares. Research in Veterinary Science, v.88, p.405-410, 2010. Available from: <https://www.ncbi.nlm.nih. gov/pubmed/20022348>. Accessed: Jun. 5, 2019. doi: 10.1016/j. rvsc.2009.11.008.

GONZÁLES, F.H.D; SILVA, S.C. Introdução à bioquímica clínica veterinária. 2 ed. Ed. Porto Alegre: UFRGS, 2006.
GÓRECKA, R. et al. Changes in antioxidant components in blood of mares during pregnancy and after foaling. Bulltin of the Veterinary Institute in Pulawy, v.46, p.301-305, 2002.

HARVEY, J.W. et al. Clinical biochemistry of pregnant and nursing mares. Veterinary Clinical Pathology, v.34, p.248254, 2005. Available from: <https://onlinelibrary.wiley.com/doi/ epdf/10.1111/j.1939-165X.2005.tb00049.x>. Accessed: Feb. 17, 2016. doi: 10.1111/j.1939-165X.2005.tb00049.x.

HURA, V. et al. Changes of biochemical environment and body weight in healthy periparturient Lipizzan mares. Acta Veterinary Brno, v.86, p.67-74, 2017. Available from: <https://actavet.vfu.cz/86/1/0067/>. Accessed: Apr. 17, 2017. doi: 10.2754/avb201786010067.

JOHNSON, P.J.; MESSER, N.T.; GANJAM, S.K.; WIEDMEYER, C.E. Pregnancy-Associated Laminitis in Mares. Journal of Equine Veterinary Science, v.29, p.42-46, 2009. Available from: $<$ https://www.sciencedirect.com/science/article/ pii/S0737080608003961?via\%3Dihub>. Accessed: Jun. 10, 2019. doi: 0.1016/j.jevs.2008.11.009.

KANEKO, J.J. et al. Clinical biochemistry domestic animals. 6th ed. London: Elsevier, 2008.

KAVAZIS, A.N. et al. Supplementation of broodmares with copper, zinc, iron, manganese, cobalt, iodine, and selenium. Journal of Equine Veterinary Science, v.22, p460-464, 2002. Available from: <https:/www.sciencedirect.com/science/article/ pii/S0737080602701652>. Accessed: Dec. 5, 2017. doi: 10.1016/ S0737-0806(02)70165-2.

KIRSCHVINK, N. et al. The oxidant/antioxidant equilibrium in horses. Veterinary Journal, v.177, p.178-191, 2008. Available from: $<$ https://doi.org/10.1016/j.tvj1.2007.07.033>. Accessed: Dec. 5, 2017. doi: 10.1016/j.tvj1.2007.07.033.

LITTELL, R.C. et al. SAS ${ }^{\circledR}$ for mixed models. 2th ed. Cary, NC: SAS Institute Inc, 2006.

MANSO FILHO, H.C. et al. Changes in glutamine metabolism indicate a mild catabolism state in the transition mare. Journal of Animal Science, v.86, p.3424-3431, 2008. Available from: $<$ https://www.ncbi.nlm.nih.gov/pubmed/19036697>. Accessed: Dec. 29, 2017. doi: 10.2527/jas.2008-1054.

MARIELLA, J. et al. Hematologic and biochemical profiles in Standardbred mares during peripartum. Theriogenology, v.81, p.526-534, 2014. Available from: <https:/www.ncbi.nlm.nih.gov/ pubmed/24361129>. Accessed: Dec. 11, 2015. doi: 10.1016/j. theriogenology.2013.11.001.

MENEZES, R.M.; RIBEIRO FILHO, J.D. Concentrações de cálcio, magnésio, fósforo e glicose de vacas leiteiras no pós-parto. Veterinaria e Zootecnia, v.18, p.552-555, 2011.

NAGEL, C. et al. Changes in blood pressure, heart rate, and blood profile in mares during the last 3 months of gestation and the peripartum period. Theriogenology, v.86, p.18561864, 2016. Available from: <https://www.ncbi.nlm.nih.gov/ pubmed/27393220>. Accessed: Feb. 20, 2017. doi: 10.1016/j. theriogenology.2016.06.001.

NASEEMA, U. et al. Serum biochemical profile during gestation period Thoroughbred mare in Chennai. The Indian Veterinary Journal, v. 92, p. 32-34, 2017. 
SAS INSTITUTE INC. SAS/STAT ${ }^{9} 9.0$ User's guide. Cary, NC: SAS Institute Inc, 2002

SANTOS, E.M. et al. Lactação em éguas da raça Mangalarga Marchador: Produção e composição do leite e ganho de peso dos potros lactentes. Revista Brasileira de Zootecnia, v.34, p.627-634, 2005. Available from: $\quad<$ http://www.scielo.br/pdf/rbz/v34n2/25476. pdf>. Accessed: Sep. 3, 2016. doi: 10.1590/S151635982005000200032 .
TALBOT, L.; MACLENNAN, K. Physiology of pregnancy. Journal of Anaesthesia Intensive Care, v.17, p.341-345, 2016. Available from: $<$ https://www.anaesthesiajournal.co.uk/article/S1472-0299(16)300273/abstract>. Accessed: Dec. 13, 2017. doi: 10.1016/j.mpaic.2016.04.010.

VINCZE, B. et al. Pregnancy-associated changes of sérum biochemical values in Lipizzaner Broodmares. Acta Veterinary Hungarica, v.63, p.303-316, 2015. Available from: $<$ https://core. ac.uk/download/pdf/42945669.pdf>. Accessed: Mar. 9, 2016. doi: 10.1556/004.2015.028. 